\title{
Pengaruh Tingkat Profitabilitas Tehadap Harga Saham dan Implikasinya pada Indeks Harga Saham di Bursa Efek Indonesia
}

\author{
Irma Nurmala Dewi ${ }^{1}$
}

\begin{abstract}
Abstrak
Sebelum seorang investor mengambil keputusan untuk berinvestasi di suatu perusahaan, maka ia harus mengetahui informasi mengenai kinerja dan prospek masa depan perusahaan tersebut. Data yang bisa digunakan untuk mengetahui kinerja sebuah perusahaan adalah melalui dividen per share dan earning per share-nya. Earning per share memberikan gambaran mengenai prestasi perusahaan dalam memperoleh keuntungan sehingga investor akan meyakini dana yang diinvestasikannya akan memperoleh imbalan. Demikian pula jika perusahaan memutuskan untuk membagikan dividen per share, hal ini akan disambut positif oleh investor yang menginginkan pembagian keuntungan atas lembar saham yang dimilikinya.

Penelitian ini bertujuan untuk mengetahui pengaruh dividen per share dan earning per share terhadap harga saham perusahaan di BEl. Objek yang diambil adalah sebanyak 21 (dua puluh satu) perusahaan emiten berjenis manufaktur yang terdaftar di BEI dengan periode pengamatan 2005 sampai dengan 2009 (lima tahun berturut-turut), sehingga beriumlah 105 sampel observasi. Metode analisis statistik yang digunakan adalah Model Regresi Linier Berganda (Multiple Linear Regression) untuk melihat hubungan kausal antara variabel independent dengan variabel dependent.

Berdasarkan hasil analisis, secara parsial baik variabel dividen per share maupun earning per share sama-sama memiliki pengaruh yang positif dan signifikan terhadap harga saham. Secara simultan keduanya bersama-sama berpengaruh secara signifikan terhadap harga saham. Variansinya terjelaskan dalam Adjusted $R$ Square $\left(R^{2}\right)$ sebesar 0,888 berarti 88,8\% perubahan Harga Saham dapat dijelaskan oleh variabel DPS dan EPS. Sedangkan sisanya sebesar 11,2\% dijelaskan oleh variabel lain yang tidak termasuk ke dalam model penelitian ini. Hasil penelitian menunjukkan bahwa dividen per share dan earning per share berpengaruh terhadap harga saham. Dengan demikian hasil penelitian mendukung hipotesis yang ada.
\end{abstract}

Kata Kunci : Bursa Efek Indonesia, Harga Saham, Indeks Harga Saham Profitabilitas

\section{Pendahuluan}

Dunia investasi pada pasar modal di Indonesia sendiri masih sedikit sekali investor yang mau menanamkan modal pada sector ini. Hanya beberapa orang dan bahkan tidak mencapai dari 5\% jumlah investor lokal yang menginvestasikan modalnya pada pasar bursa ataupun pasar indeks saham di Indonesia.

Rendahnya tingkat pengetahuan mengenai bidang investasi pada pasar modal sendiri membuat para investor merasa takut dan tidak yakin akan memberikan modalnya dan kemudian bermain pada lantai bursa saham itu sendiri. Walaupun di Indonesia sendiri telah banyak perusahaan yang terdaftar sebagai emiten di lantai bursa Jakarta. Dari sekian banyak emiten dengan instrumen investasi yang mereka tawarkan masing-masing, investor dapat berinvestasi pada satu atau beberapa instrumen yang ada. Masalahnya adalah, di antara semua instrumen tersebut, manakah yang sekiranya baik dan tepat sehingga nantinya mampu memenuhi harapan para investor.

Dalam berinvestasi, investor telah merelakan konsumsi atas sejumlah dana yang mereka miliki saat ini untuk ditukar dengan aset-aset investasi Kerelaan yang diberikan para investor ini berimbal hasil pada kemungkinan akan satu atau lebih keuntungan yang bersifat finansial. Pada saham contohnya, investor pemegang instrumen investasi ini bisa mendapatkan dua bentuk keuntungan financial, dividen (bagi investor yang lebih menginginkan mendapatkan hak kepemilikan atas perusahaan) dan capital gain (bagi investor yang lebih 
menginginkan keuntungan cepat). Dividen adalah merupakan satu-satunya bentuk pembayaran tunai yang diberikan oleh perusahaan emiten kepada para pemegang sahamnya (Jones 2004). Sedangkan capital gain adalah keuntungan tambahan yang bisa didapat investor dari hasil selisih harga pembelian saham dengan harga ketika dilakukan penjualan atas saham tersebut (Keown 2001).

Dalam tahun terakhir ini seiring dengan membaiknya perekonomian Indonesia jumlah emiten yang ada di Bursa Efek Indonesia meningkat. Meningkatnya jumlah emiten akan membawa kearah yang lebih baik pihak-pihak yang berkepentingan, antara lain bagi perusahaan akan lebih mudah dalam memperoleh modal, dan bagi investor akan mendapatkan return. Para pemodal tertarik untuk menginvestasikan dananya karena investasi dalam bentuk saham menjanjikan tingkat keuntungan yang lebih tinggi, baik dari deviden maupun dari capital gain. Akan tetapi investasi dalam bentuk saham juga mempunyai resiko yang tinggi sesuai dengan prinsip investasi yaitu low risk low return high risk high return. Untuk mengurangi resiko saham dibutuhkan informasi yang aktual, akurat dan transparan. Para investor dalam melakukan transaksi jual beli saham tentunya dipengaruhi oleh beberapa faktor, yaitu faktor mikro perusahaan dan faktor makro ekonomi. Faktor mikro (internal perusahaan) yang mempengaruhi transaksi perdagangan saham antara lain: harga saham, tingkat keuntungan yang diperoleh, tingkat resiko, kinerja perusahaan dan corporate action yang dilakukan perusahaan tersebut. Sedangkan faktor makro (eksternal perusahaan) adalah tingkat perkembangan inflasi, nilai tukar atau kurs rupiah, keadaan perekonomian, dan kondisi sosial politik negara yang bersangkutan. Investor yang mengharapkan capital gain memiliki prediksi serta pengharapan akan adanya kenaikan harga pada saham yang ingin dibelinya pada saat melakukan pembelian.

Kenaikan terhadap harga saham inilah yang nantinya akan memberikan return positif bagi investor ketika ia menjual kembali saham yang dimilikinya tersebut. Informasi keuangan sebagai instrumen data akuntansi diharapkan mampu menggambarkan realita ekonomi. Oleh karena itu pengujian terhadap kandungan informasi akan dapat mempengaruhi reaksi pasar atas tingkat pengembalian (return). Salah satu alternatif untuk mengetahui informasi keuangan yang dihasilkan bermanfaat untuk memprediksi harga saham, maka dilakukan analisis rasio keuangan. Menurut Penman $(1991 ; 48)$ seperangkat laporan keuangan utama belum dapat memberikan manfaat maksimal bagi pemakai sebelum pemakai menganalisis laporan keuangan tersebut dalam bentuk rasio keuangan. Rasio keuangan menurut (Bambang Riyanto 1999) dikelompokkan dalam lima jenis yaitu (1) rasio likuiditas, (2) rasio aktivitas, (3) rasio profitabilitas, (4) rasio solvabilitas (5) rasio pasar. Harga saham adalah nilai suatu saham yang mencerminkan kekayaan perusahaan yang mengeluarkan saham tersebut, dimana perubahan atau fluktuasinya sangat ditentukan oleh kekuatan penawaran dan permintaan yang terjadi di bursa (pasar sekunder). Semakin banyak investor yang ingin membeli atau menyimpan suatu saham, harganya semakin naik, sebaliknya semakin banyak investor yang ingin menjual atau melepaskan suatu saham, harganya semakin bergerak turun. Secara umum, semakin banyak kinerja suatu perusahaan semakin tinggi laba usahanya dan semakin banyak keuntungan yang dapat dinikmati oleh pemegang saham, juga semakin besar kemungkinan harga saham akan naik (Koetin 1997).

Meskipun demikian saham yang memiliki kinerja baik sekalipun, harganya bisa saja turun karena keadaan pasar. Saham yang memiliki kinerja baik meskipun harganya menurun keras karena keadaan pasar yang jelek (bearish) yang menyebabkan kepercayaan terhadap pemodal terguncang, saham ini tidak akan sampai hilang jika kepercayaan pemodal pulih. Siklus ekonomi membaik ataupun hal-hal lain membaik (bullish), maka harga saham yang baik ini akan kembali naik menjadi resiko dari pemegang suatu saham adalah turunnya harga saham. Cara mengatasinya adalah menahan saham tersebut untuk waktu yang cukup lama sampai keadaan pasar membaik kembali. Dalam melakukan prediksi harga saham terdapat pendekatan dasar yaitu analisis fundamental dan analisis teknikal. Secara tradisional analisis fundamental telah memperoleh perhatian yang cukup besar dari para analisis sekuritas. Para praktisi cenderung menyukai penggunaan model yang tidak terlalu rumit, mudah dipahami, dan mendasarkan diri atas informasi akuntansi. Husnan $(2001 ; 303)$ menjelaskan bahwa analisis fundamental mendasarkan pola pikir perilaku harga saham ditentukan oleh perubahan-perubahan variasi perilaku variabel-variabel dasar kinerja perusahaan. Secara ringkas dapat dikatakan bahwa harga saham tersebut ditentukan oleh nilai 
perusahaan. (Halim 2003) mendukung pernyataan diatas bahwa ide dasar pendekatan ini adalah bahwa harga saham dipengaruhi oleh kinerja perusahaan. Apabila kinerja perusahaan baik maka nilai usaha akan tinggi. Dengan nilai usaha yang tinggi membuat para investor melirik perusahaan tersebut untuk menanamkan modalnya sehingga akan terjadi kenaikan harga saham. Sebaliknya apabila terdapat berita buruk mengenai kinerja perusahaan maka akan menyebabkan penurunan harga saham pada perusahaan tersebut. Atau dapat dikatakan bahwa harga saham merupakan fungsi dari nilai perusahaan. Kinerja perusahaan ini akan menjadi tolak ukur seberapa besar resiko yang akan ditanggung investor.

Untuk memastikan kinerja perusahaan tersebut dalam kondisi baik atau buruk dapat dilakukan dengan menggunakan analisis rasio. Analisis teknikal adalah menganalisis harga saham berdasarkan informasi yang mencerminkan kondisi perdagangan saham, keadaan pasar, permintaan dan penawaran harga di pasar saham, fluktuasi kurs, volume transaksi di masa lalu. Analisis teknikal menegaskan bahwa perubahan harga saham terjadi berdasarkan pola perilaku harga saham itu sendiri, sehingga cenderung untuk terulang kembali. Asumsi dasar dari analisis teknikal adalah bahwa jual beli saham merupakan kegiatan berspekulasi (Husnan 2003). Return positif hanya didapat jika harga jual saham lebih besar dibanding harga pembeliannya. Dalam melakukan prediksi akan kondisi harga saham di masa datang, investor tidak hanya mengandalkan keberuntungan semata. Saham yang nantinya akan mengalami kenaikan harga dapat diketahui melalui sebuah proses analisa. Dalam melakukan analisa ini, investor harus membekali dirinya dengan pengetahuan akan bagaimana proses pembentukan harga terjadi pada sebuah saham atau setidaknya investor harus mengetahui variabel-variabel apa saja yang dapat mempengaruhi return sebuah saham agar ekspektasi mereka akan return di masa datang dapat diperoleh sehingga usaha dalam mencari return positif bisa diwujudkan. Dari beberapa penilaian investasi tentu saja akan terdapat beberapa kesimpulan dan juga alternative atas penilaian investasi salah satunya yaitu analisis secara fundamental. Analisis fundamental disini digunakan oleh para investor untuk meramal masa depan portofolio yang dipilihnya berdasarkan fenomena perusahaan yang digambarkan dari data sekunder perusahaan. Profitabilitas perusahaan adalah salah satu cara untuk menilai secara tepat sejauh mana tingkat pengembalian yang akan didapat dari investasi atau modal yang telah ditanam. Investor menilai sebuah perusahaan tersebut akan menguntungkan dimasa mendatang dan dana mereka akan berkembang serta aman maka banyak investor yang akan menanamkan modalnya pada perusahaan tersebut.

Jika para investor banyak menanamkan modal dalam jumlah besar pada suatu perusahaan tentu saja akan membuat harga saham melonjak tinggi. Walaupun pada saat ini kegiatan investasi pada lantai bursa masih cenderung hanya untuk masyarakat yang memiliki modal lebih tapi hal ini juga memicu untuk bergabungnya investor asing untuk ikut serta menanamkan modal pada perusahaan yang bonafit. Kinerja perusahaan dapat diukur dari kemampuan perusahaan dalam memenuhi kewajibannya pada para penyandang dana, jika perusahaan tersebut memiliki kinerja yang baik maka para investor akan menanamkan modalnya karena akan mendapatkan keuntungan dengan menanamkan modalnya. Fenomena harga saham pada BEl juga meningkat dari tahun ketahun yang menunjukan bahwa perusahaan yang tercatat pada BEI merupakan perusahaan yang tergolong besar dan dapat bertahan oleh berbagai rintangan. Salah satu contoh emiten yang sangat cepat mengalami kenaikan adalah saham pertambangan. Sebelum 2005, saham perusahaan pertambangan bukanlah komoditas yang menarik di lantai bursa. Karena, para pemain saham cenderung mengincar untung besar dalam jangka pendek dengan risiko yang minim. Sedangkan pertambangan merupakan investasi besar jangka panjang yang berisiko besar. Namun saat ini, pandangan itu berbalik 180 derajat. Seiring melonjaknya harga komoditas pertambangan, saham perusahaan tambang yang tercatat di Bursa Efek Indonesia (BEl) juga menjadi primadona. Pelaku bursa semakin yakin akan prospek perusahaan tambang, mengingat tingginya harga masih akan bertahan hingga beberapa tahun kedepan.

Meningkatnya ketertarikan pada sumber energi pengganti minyak bumi, menjadi penyumbang terbesar booming-nya saham-saham pertambangan. Selain itu, pertumbuhan industri di China dan India, juga Korea dan Jepang, membutuhkan suplai batubara dalam jumlah sangat besar dari Asia khususnya Indonesia. Faktor tersebut ikut menjadi pengerek nilai saham perusahaan 
pertambangan batubara di lantai bursa. Kemampuan perusahaan itu sendiri dalam mengukur tingkat kemajuan perusahaan dalam menghasilkan laba dari investasi yang dilakukan disebut dengan rasio profitabilitas. Tingkat profitabilitas pada analisa fundamental dapat diukur dari beberapa aspek, yaitu Profit Margin, ROl (Return on Invesment), EPS (Earning per Share), ROE (Return on Equity). Penelitian yang dilakukan sebelumnya dengan menggunakan metode fundamental ataupun teknikal tidak mengalami hambatan yang signifikan dalam melakukan penelitian.

Investasi di pasar modal merupakan jenis investasi yang memiliki risiko cukup tinggi sehingga diperlukan informasi-informasi untuk mengetahui faktor apa saja yang akan mempengaruhi fluktuasi harga saham dan juga mengetahui bagaimana hubungan variabel-variabel tersebut dengan harga saham. Analisis fundamental sendiri merupakan analisa yang sering dan paling mudah untuk mengetahui harga saham dimasa depan sehingga investor dapat menentukan perusahaan mana yang tepat untuk menanamkan modalnya. Analisa fundamental sendiri tidak akan lepas dari analisis teknikal yang menggunakan data pada masa lalu untuk mengetahui harga saham dimasa mendatang. Variabel-variabel tersebut akan membentuk kekuatan pasar yang berpengaruh terhadap transaksi saham perusahaan sehingga harga saham akan mengalami kenaikan atau penurunan harga yang signifikan.

\section{Kerangka Pemikiran}

Pergerakan saham pada umumnya akan bergerak secara signifikan dan tidak akan sama setiap harinya. Akan terdapat kenaikan atau penurunan terhadap harga saham yang dipengaruhi oleh beberapa faktor yang memicu akan perubahan harga saham tersebut. Faktor-faktor tersebut dapat dipengaruhi dari dalam perusahaan itu sendiri ataupun dari luar perusahaan atau sering disebut dengan faktor fundamental. Faktor fundamental adalah faktor yang mempengaruhi harga saham dari bidang ekonomi, politik, serta keamanan negara. Analisis fundamental berbeda dengan analisis teknikal yang lebih condong mengarah pada pergerakan grafik atau software (perangkat lunak) yang dapat membantu para pialang dalam menentukan harga saham.

Dalam analisis fundamental, proyeksi harga saham dilakukan dengan mempertimbangkan proyeksi prestasi perusahaan dimasa depan. Prestasi perusahaan yang dinilai dikaitkan dengan kondisi fundamental atau kinerja keuangan perusahaan. Kondisi fundamental mencerminkan kinerja variable-variabel keuangan yang dianggap mendasar atau penting dalam perubahan harga saham. Para penganut analisis fundamental berasumsi bahwa apabila kondisi fundamental atau kinerja keuangan perusahaan semakin baik maka harga saham yang diharapkan juga akan mengalami kenaikan (Husnan 2003). Sebaliknya apabila terdapat berita buruk mengenai kinerja perusahaan maka akan menyebabkan penurunan harga saham pada perusahaan tersebut. Kinerja perusahaan ini akan menjadi tolak ukur seberapa besar rasio resiko yang ditanggung investor. Untuk memastikan kinerja perusahaan tersebut dalam kondisi baik atau buruk dapat dilakukan dengan menggunakan analisis rasio.

Perubahan harga saham di pasar modal dipengaruhi oleh beberapa faktor yang salah satunya adalah faktor internal perusahaan. Faktor dalam perusahaan itu sendiri mempunyai pengaruh yang signifikan terhadap kondisi pergerakan saham atau emiten yang diperjual belikan di lantai bursa. Hak ini dapat dilihat dari laporan keuangan perusahaan itu sendiri apakah mengalami kenaikan atau penurunan laba perusahaan. Kinerja perusahaan merupakan faktor internal perusahaan yang dapat dilihat melalui rasio-rasio keuangan perusahaan tersebut. Dalam sebuah transaksi jual beli saham tentu saja harus dilakukan melalui sebuah wadah atau perusahaan yang mengelola semua saham yang telah go public, dan merupakan anggota emiten yang telah memenuhi syarat untuk bergabung mentransaksikan saham-saham perusahaan mereka. Lembaga tersebut sering dikenal dengan lantai bursa atau pasar modal.

Salah satu fungsi dari pasar modal itu sendiri adalah sebagai sarana untuk memobilisasi dana yang bersumber dari masyarakat (investor) ke berbagai sektor yang melaksanakan investasi. Syarat utama yang diinginkan oleh investor untuk bersedia menyalurkan dananya melalui pasar modal adalah perasaan aman untuk menginvestasikannya. Perasaan aman ini diantaranya karena para investor memperoleh infomasi yang jelas, wajar dan tepat waktu sebagai dasar dalam pengambilan keputusan. Saham- saham atau indeks saham yang go public sebagai komoditi investasi memiliki keunikan tersendiri, karena sifatnya sangat peka terhadap perubahan 
lingkungan bisnis. Perubahan tersebut dapat berdampak positif dan dapat pula berdampak negative. Oleh karena itu para investor memerlukan informasi-informasi akurat sebagai bahan pertimbangan dalam menentukan pilihan dalam membeli saham agar memperoleh return yang diharapkan. Dalam melakukan transaksi para investor tidak dapat melakukan transaksi saham sendiri karena pihak investor hanyalah sebagai pemberi modal untuk mendapatkan keuntungan, transaksi tersebut dapat diwakilkan kepada para wakil pialang yang secara legal mempunyai keahlian dalam bidang transaksi saham.

Kinerja para pialang terhadap mengelola dana merupakan salah satu faktor yang dilihat para investor dalam melakukan dan mengolah transaksi dari modal yang telah diberikan oleh para investor untuk diinvestasikan. Dalam hal ini wakil pialang harus mempunyai keahlian dalam analisis teknikal dalam menentukan profitabilitas saham serta indeks saham yang memerlukan suatu analisa yang dilakukan oleh wakil pialang dalam melakukan transaksi.

Dari uraian diatas maka dapat ditarik kesimpulan mengenai kerangka pemikiran dalam melakukan penelitian ini. Kerangka berfikir dalam penelitian ini mengemukakan sistematika kerangka konseptual tentang pengaruh beberapa faktor fundamental, yang terdiri rasio profitabilitas yakni Profit Margin, ROI (Return on Invesment), EPS (Earning Per Share), ROE (Return on Equity), terhadap harga saham dan implementasinya pada IHSG di Bursa Efek Indonesia (BEl) nampak seperti pada Gambar 1 berikut:

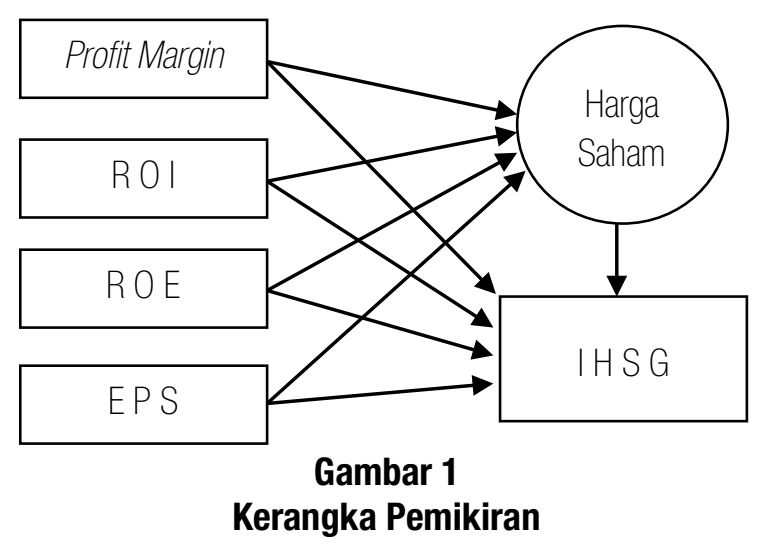

\subsection{Perumusan Hipotesis}

Berdasarkan hubungan antara landasan teori, kerangka pemikiran terhadap rumusan masalah maka hipotesis atau jawaban sementara dari permasalahan dalam penelitian ini adalah:

1. H1 : Profit Margin secara parsial mempunyai pengaruh terhadap harga saham.

2. H2 : Return On investment (ROI) secara parsial mempunyai pengaruh terhadap harga saham.

3. H3 : Return On Equity (ROE) secara parsial mempunyai pengaruh terhadap harga saham.

4. H4 : Earning Per Share (EPS) secara parsial mempunyai pengaruh terhadap harga saham.

5. H5 : Profit margin secara parsial mempunyai pengaruh terhadap Indeks Harga Saham.

6. H6 : Return On equity (ROE) secara parsial mempunyai pengaruh terhadap Indeks Harga Saham.

7. H7 : Return On Investment (ROI) secara parsial mempunyai pengaruh terhadap Indeks Harga Saham.

8. H8 : Earning per Share (EPS) secara parsial mempunyai pengaruh terhadap Indeks Harga Saham.

9. H9 : Harga saham secara parsial mempunyai pengaruh terhadap Indeks Harga Saham.

\section{Metode Penelitian}

Metode yang dilakukan untuk mendapatkan data yang diinginkan adalah sebagai berikut :

1. Observasi tidak langsung

2. Penelitian kepustakaan

Adapun teknik pengumpulan data yang digunakan adalah dengan pooled data yang merupakan kombinasi antara time series dan cross section.

Variabel dalam penelitian ini terdiri dari Variabel tidak bebas $(Y)$, adalah harga Saham (Y) dan IHSG (Z) variabel bebas terdiri dari Profit Margin (X1), ROI (X2), ROE (X3), EPS (X4).

Populasi dalam penelitian ini adalah seluruh sahamsaham pertambangan yang tercatat di Bursa Efek Indonesia (BEl) selama periode 2002-2007. Pemilihan sampel dalam penelitian ini dilakukan secara Multi Shapes Purpose Sampling sebanyak 17 Perusahaan.

Uji normalitas dengan menggunakan SPSS adalah dengan uji Kolmogrov Smirnov, Shapiro Wilk dan gambar Normal Probability Plots sedangkan kesamaan varians (homogenitas) diuji dengan liliefors. Imam Ghozali (2002), menyatakan bahwa uji normalitas adalah untuk menguji apakah model regresi, variabel independen, dan variabel dependen-nya memiliki distribusi data normal atau tidak. 
Penelitian ini menggunakan Analisis jalur (Path Analysis). Path analysis digunakan apabila secara teori kita yakin berhadapan dengan masalah yang berhubungan sebab akibat.

\section{Hasil Pengujian}

\subsection{Perhitungan Koefisien Jalur}

Untuk memperoleh koefisien jalur, pertama-tama kita mencari koefisien korelasi di antara variabel bebas. Dari hasil pengolahan data diperoleh matriks korelasi antar variabel bebas $(X)$ seperti di bawah ini:

$$
R=X_{1} X_{2}\left[\begin{array}{cccc}
X_{1} & X_{2} & X_{3} & X_{4} \\
X_{3}, 000 & -0,354 & -0,928 & -0,114 \\
-0,354 & 1,000 & 0,270 & 0,589 \\
X_{4}
\end{array}\left[\begin{array}{cccc}
-0,928 & 0,270 & 1,000 & 0,091 \\
-0,114 & 0,589 & 0,091 & 1,000
\end{array}\right]\right.
$$

Nilai korelasi antar variabel di atas kemudian dicari invers-nya, dan diperoleh hasil sebagai berikut:

$$
\mathrm{R}^{-1}=\mathrm{X}_{2} \mathrm{X}_{2} \mathrm{X}_{3}\left[\begin{array}{cccc}
\mathrm{X}_{1} & \mathrm{X}_{2} & \mathrm{X}_{3} & \mathrm{X}_{4} \\
7,929 & 1,133 & 7,086 & -0,406 \\
1,133 & 1,813 & 0,652 & -0,998 \\
7,086 & 0,652 & 7,421 & -0,250 \\
-0,406 & -0,998 & -0,250 & 1,564
\end{array}\right]
$$

Selanjutnya dicari matriks korelasi antara variabel bebas $X$ dengan $Y$ :

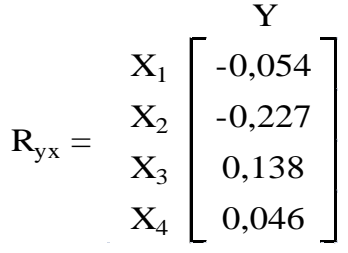

Untuk memperoleh koefisien jalur, maka matriks invers korelasi dikalikan dengan matriks korelasi antar variabel bebas $X$ dengan variabel terikat $Y$, sebagai berikut:

$$
\begin{aligned}
& \rho \mathrm{YX}_{1} \\
& \rho \mathrm{YX}_{2} \\
& \rho \mathrm{YX}_{3} \\
& \rho \mathrm{YX}_{4}
\end{aligned}=\left[\begin{array}{cccc}
7,929 & 1,133 & 7,086 & -0,406 \\
1,133 & 1,813 & 0,652 & -0,998 \\
7,086 & 0,652 & 7,421 & -0,250 \\
-0,406 & -0,998 & -0,250 & 1,564
\end{array}\right] \times\left[\begin{array}{c}
-0,054 \\
-0,227 \\
0,138 \\
0,046
\end{array}\right]
$$

$$
\begin{aligned}
& \rho \mathrm{YX}_{1} \\
& \rho \mathrm{YX}_{2} \\
& \rho \mathrm{YX}_{3} \\
& \rho \mathrm{YX}_{4}
\end{aligned}=\left[\begin{array}{c}
0,273 \\
-0,430 \\
0,481 \\
0,287
\end{array}\right]
$$

Koefisien jalur dan koefisien korelasi yang telah diperoleh tersebut jika disajikan pada diagram jalur adalah sebagai berikut:

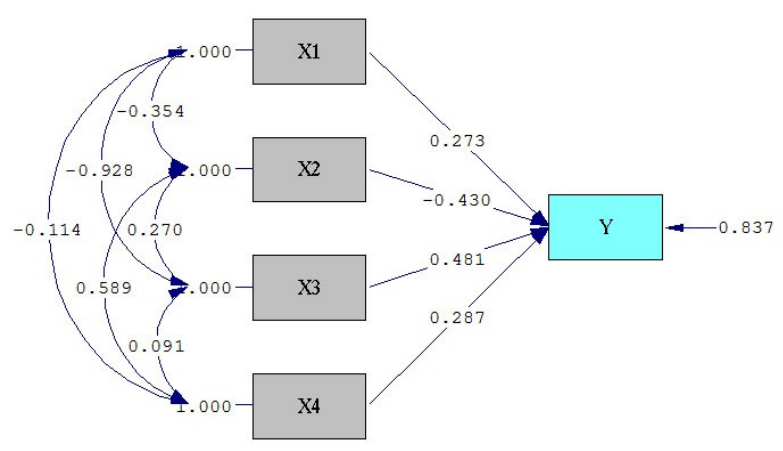

\section{Gambar 2}

\section{Koefisien Jalur Variabel X Terhadap Variabel Y}

Setelah koefisien jalur diperoleh, maka besar pengaruh Profit Margin (X1), ROE (X2), ROI (X3), dan EPS (X4) secara bersama-sama terhadap Harga Saham (Y) dapat ditentukan dari hasil perkalian koefisien jalur terhadap matriks korelasi antara variabel sebab $X$ dengan variabel akibat $Y$.

$$
\begin{aligned}
\mathrm{R}_{\mathrm{Y}(\mathrm{X} 1 \mathrm{X} 2 \mathrm{X} 3 \mathrm{X} 4)} & =\left[\begin{array}{llll}
0,273 & -0,430 & 0,481 & 0,287
\end{array}\right] \times\left[\begin{array}{c}
-0,054 \\
-0,227 \\
0,138 \\
0,046
\end{array}\right] \\
& =0,1626=16,26 \%
\end{aligned}
$$

Sedangkan besar koefisien jalur untuk faktor lain yang tidak masuk dalam spesifikasi adalah:

$$
\rho \bigvee \varepsilon=\sqrt{1-0,1626}=0,915
$$

Atau, jika dalam prosentase, besarnya pengaruh dari variabel lain yang tidak diamati adalah sebesar 100\% $16,26 \%=83,74 \%$. 


\subsection{Pengujian Hepotesis}

\subsubsection{Uji Simultan (Keseluruhan)}

$$
\begin{aligned}
& H_{0}= \rho_{Y X 1}=\rho_{Y X 2}=\rho_{Y X 3}=\rho_{Y X 4}=0 \\
& H_{1}=\text { sekurang-kurangnya ada sebuah } \\
& \boldsymbol{\rho}_{Y X i} \neq 0, i=1,2,3,4
\end{aligned}
$$

Uji statistik yang digunakan adalah:

$$
\begin{aligned}
& F=\frac{(n-k-1) \sum_{i=1}^{n} P_{Y X i} r_{Y X 1}}{k\left\{1-\sum_{i=1}^{n} P_{Y X i} r_{Y X 1}\right\}} \\
& F=\frac{(17-4-1) \times 0,1626}{4\{1-0,1626\}}=0,583
\end{aligned}
$$

Uji statistik di atas mengikuti distribusi F-Snodecor dengan $\boldsymbol{\alpha}=5 \%$, derajat kebebasan $\mathrm{db}_{1}=4$, dan $\mathrm{db}_{2}=$ 17-4-1 $=12$, diperoleh $F$ tabel $=3,259$. Dari hasil $d i$ atas dapat dilihat bahwa $F$ hitung $<F$ tabel $(0,583<$ $3,259)$ sehingga sesuai dengan kriteria uji simultan adalah tolak $\mathrm{H}_{0}$, artinya sub variabel bebas secara bersama-sama tidak berpengaruh signifikan terhadap variabel Harga Saham.

\subsubsection{Uji Parsial (Individu)}

Setelah melakukan uji simultan dengan hasil yang signifikan, maka selanjutnya dilakukan uji parsial untuk melihat sub variabel bebas mana saja yang berpengaruh terhadap Harga Saham. Untuk pegujian ini digunakan uji t, yang diperoleh hasil seperti pada Tabel 1 berikut:
Tabel 1

Pengujian Hipotesis Parsial

\begin{tabular}{|c|c|c|c|}
\hline Koefisien Jalur & t-hitung & t-tabel & Kesimpulan \\
\hline $\boldsymbol{\rho} Y X 1=0,273$ & 0,367 & $-2,179$ dan 2,179 & Ho Diterima \\
\hline $\boldsymbol{\rho} Y X 2=-0,43$ & $-1,208$ & $-2,179$ dan 2,179 & Ho Diterima \\
\hline $\boldsymbol{\rho} Y X 3=0,481$ & 0,669 & $-2,179$ dan 2,179 & Ho Diterima \\
\hline $\boldsymbol{\rho} Y X 4=0,287$ & 0,867 & $-2,179$ dan 2,179 & Ho Diterima \\
\hline
\end{tabular}

- Profit Margin (X1) tidak berpengaruh signifikan terhadap Harga Saham (Y), dimana -t tabel

$(-2,179)<$ thitung $(0,367)<$ t tabel $(2,179)$.

- ROE (X2) tidak berpengaruh signifikan terhadap Harga Saham $(Y)$, dimana - $t$ tabel $(-2,179)<$ t hitung $(0,669)<$ t tabel $(2,179)$.

- ROI (X3) tidak berpengaruh signifikan terhadap Harga Saham (Y), dimana -t tabel $(-2,179)<$ t hitung $(-1,208)<$ t tabel $(2,179)$.

- EPS (X4) tidak berpengaruh signifikan terhadap Harga Saham (Y), dimana -t tabel $(-2,179)<$ t hitung $(0,867)<$ t tabel $(2,179)$.

\subsection{Pengaruh Langsung dan Pengaruh Tidak Langsung Variabel Bebas terhadap Variabel Terikat}

Berdasarkan hasil penelitian, diperoleh kesimpulan yaitu terdapat pengaruh Profit Margin (X1), ROE (X2), ROI (X3), dan EPS (X4) secara bersama-sama terhadap Harga Saham (Y).

Untuk melihat lebih jauh tentang besar pengaruh langsung dan tidak langsung dari masing-masing sub variabel bebas terhadap variabel terikat, sehingga secara statistik dinyatakan tidak berpengaruh, berikut disajikan

\begin{tabular}{|c|c|c|c|c|c|c|c|c|}
\hline \multirow{2}{*}{ Variabel } & \multirow{2}{*}{$\begin{array}{l}\text { Koefisien } \\
\text { Jalur }\end{array}$} & \multirow{2}{*}{$\begin{array}{l}\text { Pengaruh } \\
\text { Langsung }\end{array}$} & \multicolumn{4}{|c|}{ Pengaruh tidak langsung melalui: } & \multirow{2}{*}{$\begin{array}{c}\text { Pengaruh Tidak } \\
\text { Langsung }\end{array}$} & \multirow{2}{*}{ Total Pengaruh } \\
\hline & & & $x_{1}$ & $x_{2}$ & $x_{3}$ & $x_{4}$ & & \\
\hline$X_{1}$ & 0,273 & $7,46 \%$ & - & $4,15 \%$ & $-12,20 \%$ & $-0,90 \%$ & $-8,94 \%$ & $-1,48 \%$ \\
\hline$X_{2}$ & $-0,430$ & $18,45 \%$ & $4,15 \%$ & - & $-5,58 \%$ & $-7,25 \%$ & $-8,68 \%$ & $9,77 \%$ \\
\hline$X_{3}$ & 0,481 & $23,18 \%$ & $-12,20 \%$ & $-5,58 \%$ & - & $1,26 \%$ & $-16,53 \%$ & $6,65 \%$ \\
\hline$X_{4}$ & 0,287 & $8,21 \%$ & $-0,90 \%$ & $-7,25 \%$ & $1,26 \%$ & - & $-6,89 \%$ & $1,32 \%$ \\
\hline \multicolumn{8}{|c|}{ Total Pengaruh } & $16,26 \%$ \\
\hline
\end{tabular}
rincian pengaruh langsung dan tidak langsungnya.

Tabel 2

Dekomposisi pengaruh langsung dan tidak langsung dari sub variabel bebas $X 1, X 2, X 3$, dan $X 4$ terhadap variabel terikat $Y$ 
- Profit Margin (X1) tidak berpengaruh signifikan terhadap Harga Saham (Y) sebagaimana telah di sajikan pada uji-t dengan total pengaruh hanya sebesar $-1,48 \%$, terdiri atas pengaruh langsung sebesar $7,46 \%$ dan pengaruh tidak langsung sebesar -8,94\%.

- ROE (X2) tidak berpengaruh signifikan terhadap Harga Saham (Y) sebagaimana telah di sajikan pada uji-t dengan total pengaruh sebesar 6,65\%, terdiri atas pengaruh langsung sebesar 23,18\% dan pengaruh tidak langsung sebesar $-16,53 \%$.

- ROI (X3) tidak berpengaruh signifikan terhadap Harga Saham (Y) sebagaimana telah di sajikan pada uji-t dengan total pengaruh sebesar 9,77\%, terdiri atas pengaruh langsung sebesar 18,45\% dan pengaruh tidak langsung sebesar -8,68\%.

- EPS (X4) tidak berpengaruh signifikan terhadap Harga Saham (Y) sebagaimana telah di sajkkan pada uji-t dengan total pengaruh sebesar 1,32\%, terdiri atas pengaruh langsung sebesar 8,21\% dan pengaruh tidak langsung sebesar -6,89\%.

Berdasarkan hasil uji secara individu (uji t) di atas menunjukkan bahwa tidak terdapat satupun sub variabel bebas yang mempengaruhi Harga Saham (Y) secara signifikan.

Dengan demikian, secara keseluruhan keempat sub variabel bebas memberikan kontribusi pengaruh terhadap Harga Saham (Y) sebesar 16,26\% dengan pengaruh terbesar diberikan oleh sub variabel ROI (X3). Sedangkan sisa 84,74\% lainnya merupakan pengaruh dari variabel lain yang tidak diamati dalam penelitian ini.

\section{Pembahasan Hasil Penelitian}

Dari pengujian populasi sampel yaitu 34 perushaan yang tercatat sahamnya pada BEl maka pengujjan normalitas yang dilakukan didapatkan hasil data yang tidak berdistri normal, maka dari itu dilakukan eliminasi data agar mendapatkan data yang berdistribusi normal sehingga perusahaan tersebut menjadi 17 sampel. Pada pengujian hipotesis yaitu pengujian individu dimana variabel yang berpengaruh terhadap harga saham itu sendiri. Pada tingkat profitabilitas yaitu pada profit margin ROE, ROI dan EPS didapatkan hasil yang tidak berpengaruh secara signifikan terhadap harga saham.
Dimana profit margin hanya memiliki pengaruh sebesar -1,48\% hal ini dikarenakan profit margin merupakan besar keuntungan suatu perusahaan yang emitennya telah didaftarkan di lantai bursa. Faktor yang berpengaruh adalah faktor yang tidak langsung hal ini dikarenakan mungkin sebagian besar investor masih melihat tingkat keuntungan perusahaan tersebut apakah memang merupakan perusahaan yang go public atau tidak.

ROI sendiri tidak berpengaruh signifikan pada harga saham yaitu diperoleh hasil sebesar 9,77\%. Hal ini disebabkan karena Pengaruh perusahaan terhadap investasi dari para investor tidak berpengaruh besar pada transaksi saham itu sendiri. Para investor tidak melihat kedalam faktor internal perusahaan itu sendiri.

Sedangkan pada ROE didapatkan hasil sebesar 6,65\% para investor menggunakan ROE juga sebagai parameter untuk menginvestasikan dana mereka pada perusahaan yang tercatat sahamnya pada BEl. Hal yang berpengaruh dalam ROE perusahaan adalah pengaruh langsung dari perusahaan itu sendiri.

Selain itu EPS hanya memiliki pengaruh yang sangat kecil diantara komponen tingkat profitabilitas diatas yaitu sebesar 1,32\%. Hal ini dikarenakan pengaruh tidak langsung dari faktor eksternal perusahaan yang berpengaruh terhadap investor untuk memutuskan menanamkan modal pada perusahaan tersebut atau mentraksaksikan saham yang telah tercatat dilantai bursa sebagai emiten di pasar modal.

Sedangkan dalam pengujian analisis jalur pada tingkat profitabilitas yaitu pada Profit margin, ROI, ROE, dan EPS terhadap Indeks Harga Saham melalui harga saham diperoleh hasil yang tidak berpengaruh signifikan terhadap harga saham itu sendiri.

Pada profit margin dinyatakan tidak mempunyai pengaruh positif terhadap Indeks Harga Saham melalui harga saham dapat diterima.Hasil analisis ini memberikan kontribusi yang positif dan tidak berpengaruh signifikan terhadap perubahan harga saham. Yaitu kenaikan ataupun penurunan hasil keuntungan perusahaan itu sendiri mempunyai dampak yang sangat berpengaruh pada harga saham. Semakin tinggi tingkat keuntungan suatu perusahaan maka semakin yakin para investor untuk menanamkan modalnya pada perusahaan tersebut atau mentransaksikan saham yang telah go public. Berdasarkan 
hasil penelitian profit margin dapat dipakai sebagai prediktor dalam memprediksi tentang perubahan harga saham. Sehubungan dengan hal tersebut tampak bahwa para investor dalam memprediksi harga saham juga dapat memperhatikan kinerja perusahaan (emiten) dari sisi rasio profitabilitasnya terutama dalam profit margin perusahaan tersebut.

Pada Return On Investment (ROI) yang menyatakan ROI tidak mempunyai pengaruh positif terhadap Indeks Harga Saham melaui harga saham dapat diterima. Hasil yang diperoleh menyatakan bahwa ROI memiliki tingkat yang tidak berpengaruh signifikan pada perubahan harga saham. Pada kenaikan harga saham ataupun penurunan harga saham para investor dapat melihat dari ROI perusahaan (emiten) itu. Nilai ROI yang semakin tinggi akan memberikan pengaruh pada nilai harga saham yang semakin tinggi begitu pula jïka nilai ROI itu sendiri rendah maka nilai harga saham akan rendah. Investor dapat menjadikan ROI pada perusahaan sebagai prediksi harga saham pada masa mendatang dan dapat mempertimbangakan apakah perusahaan yang dipilih itu merupakan perusahaan yang tepat untuk berinvestasi atau tidak.

Pada nilai ROE menyatakan ROE tidak mempunyai pengaruh positif terhadap harga saham dapat diterima. Hasil analisis ini menunjukan bahwa perubahan nilai Return On Equity akan memberikan kontribusi yang positif dan tidak berpengaruh signifikan terhadap perubahan Indeks Harga Saham melalui harga saham. Kenaikan atau penurunan nilai ROE akan mempengaruhi harga saham. Jika nilai ROE tinggi maka harga saham akan naik dan sebaliknya jika ROE rendah maka harga saham pun rendah. Dalam penelitian ini ROE dapat dijadikan prediktor dalam memprediksi harga saham dimasa mendatang dalam jangka pendek atau panjang. Para investor pun harus memperhatikan kinerja perushaan dari sisi rasio profitabilitasnya terutama nilai ROE yang dihasilkan oleh perusahaan (emiten).

EPS melalui pengujian maka menyatakan EPS tidak mempunyai pengaruh positif terhadap Indeks Harga Saham melalui harga saham dapat diterima. Hasil analisisi ini menunjukan bahwa Earning Per Share (EPS) akan memberikan kontribusi terhadapa harga saham itu sendiri, kenaikan atau pun penurunan EPS akan memberikan dampak pada kenaikan atau penurunan Indeks Harga
Saham melalui harga saham. Hasil analisis ini mengindikasikan bahwa investor tetap akan menggunakan EPS sebagai parameter untuk mengukur kinerja perusahaan guna memprediksi harga saham dimasa mendatang yang mendasari bahwa EPS yang semakin besar akan menunjukan bahwa kemampuan perusahaan dalam menghasilkan laba bersih setelah pajak semakin meningkat.

\subsection{Implikasi Hasil Penelitian}

Dari hasil pengujian hipotesis dan analisis jalur, terlihat bahwa variabel Profit Margin, ROI, ROE, DPS, EPS, tidak berpengaruh secara serentak maupun parsial terhadap harga saham. Variabel bebas dapat menjelaskan perubahan harga saham sebesar 16,26\%, sedangkan 83,74\% dipengaruhi oleh variabel lain yang tidak diamati. Dengan demikian keempat variabel bebas yaitu Profit Margin, ROI, ROE, EPS dapat digunakan sebagai alat estimasi harga saham.

Hasil penelitian ini sedikit berbeda dengan beberapa penelitian yang telah dilakukan sebelumnya dimana rentang waktu penelitian menggunakan periode pengamatan 5 tahun, yaitu pada tahun 2002-2007, serta jenis perusahaan yang berbeda. Perusahaan pertambangan yang menjadi emiten pada pasar modal merupakan perusahaan yang telah Go Public dimana saham-sahamnya merupakan saham yang merupakan saham pilihan para investor. Naik turunnya jumlah transaksi saham pada emiten di pasar modal dikarenakan tingkat produksi atau penjualan perusahaan tersebut. Transaksi tersebut tergantung terhadap fluktuasi nilai mata uang Rupiah terhadap mata uang asing, sehingga berdampak terhadap menguatnya profit (keuntungan). Sesuai Teori Portofolio bahwa semakin berfluktuasi tingkat keuntungan suatu saham maka semakin berisiko suatu saham itu. Proporsi hutang yang tinggi berarti perusahaan pertambangan mempunyai resiko yang tinggi. Tidak signifikannya pengaruh tingkat profitabilitas perusahaan terhadap harga saham kemungkinan disebabkan oleh berbagai faktor, antara lain kondisi sosial, politik, serta ekonomi Indonesia yang tidak stabil sehingga mengakibatkan tingginya resiko bisnis serta ketidakpastian tingkat pendapatan yang akan diterima oleh investor, para pelaku pasar dalam mengambil keputusan investasi di Bursa Efek Indonesia kurang memperhatikan aspek fundamental perusahaan yang 
dalam penelitian ini diwakiil oleh rasio profitabilitas dan Indeks Harga Saham.

Akibatnya investor kurang percaya karena informasi tersebut seringkali tidak menggambarkan kondisi perusahaan yang sebenarnya. Investor di Indonesia yang lebih mengharapkan mendapat keuntungan yang cepat dalam jangka pendek sehingga investasi yang dilakukannya lebih bersifat spekulatif, serta pasar modal di Indonesia dalam hal ini Bursa Efek Indonesia masih bersifat weak from efficient sehingga harga saham yang terbentuk bukan berdasarkan informasi yang sebenarnya tentang kondisi perusahaan tetapi lebih dipengaruhi oleh gerakan harga historis (kekuatan permintaan dan penawaran saham). Implikasi penelitian ini dapat digunakan untuk menambah pengetahuan dan sebagai tambahan wacana bagi para investor sehubungan dengan meramalkan naik turunnya harga saham perusahaan di mana investor melakukan investasi dan juga bagi perusahaan/emiten agar selalu memperhatikan kinerja keuangan perusahaan dan memanage dengan teliti agar dapat berada dalam kondisi terkendali apabila terjadi peristiwa dari luar lingkungan perusahaan yang berpotensi mengancam posisi keuangan perusahaan, sehingga akan dapat menarik minat investor untuk menginvestasikan modal pada perusahaan emiten yang bersangkutan.

\section{Kesimpulan}

1. Dalam penelitian ini diperoleh hasil bahwa Profit Margin tidak berpengaruh signifikan terhadap Harga Saham, hal ini dikarenakan sebagian besar investor tidak melihat terlalu fokus terhadap laporan keuangan perusahaan, faktor fundamental dan faktor ekonomi lebih mempengaruhi investor untuk melakukan transaksi atau menanamkan modal.

2. Dalam penelitian ini didapatkan hasil bahwa ROE tidak berpengaruh signifikan terhadap Harga Saham, karena Return On Equity tidak menjadi alasan utama para investor untuk memilih perusahaan yang telah menjadi emiten untuk pilihan para investor untuk melakukan investasi jangka panjang ataupun jangka pendek.

3. Dalam penelitian ini didapatkan hasil bahwa ROI tidak berpengaruh signifikan terhadap Harga Saham, karena Return On Investment tidak memiliki pengaruh terhadap investor itu sendiri tetapi merupakan pengembalian investasi terhadap perusahaan yang telah go public.
4. Dalam penelitian ini didapatkan hasil bahwa EPS tidak berpengaruh signifikan terhadap Harga Saham, walau sebagaian besar para investor melihat harga lembar saham namum tidak semua investor melihat atau menghitung tingkat harga lembar saham setiap perusahaan (emiten) sehingga EPS sendiri tidak berpengaruh terhadap harga saham.

5. Dalam penelitian ini didapat hasil bahwa Profit Margin tidak berpengaruh signifikan terhadap Indeks Harga Saham melalui Harga Saham, karena tingkat keuntungan perusahaan ditentukan oleh asset atau dari laba dan rugi laporan keuangan perusahaan tersebut. Sehingga faktor internal perusahaan kurang diperhatikan oleh para investor untuk memutuskan berinvestasi.

6. Dalam penelitian ini didapatkan hasil bahwa ROI tidak berpengaruh signifikan terhadap Indeks Harga Saham melalui Harga Saham, karena pengaruh naik atau turunnya harga saham tidak ditentukan oleh faktor internal perusahaan pada Return On Invesment perusahaan tersebut, tetapi lebih condong pada faktor fundamental dan faktor ekonomi.

7. Dalam penelitian ini didapat hasil bahwa ROE tidak berpengaruh signifikan terhadap Indeks Harga Saham melalui Harga Saham. Karena return on equty sendiri merupakan faktor internal perusahaan dan sebagian investor hanya melihat dari faktor eksternal perusahaan seperti faktor ekonomi dan juga faktor makro ekonomi untuk memutuskan berinvestasi.

8. Dalam penelitian ini didapatkan hasil bahwa EPS tidak berpengaruh signifikan terhadap Indeks Harga Saham melalui Harga Saham, karena harga perlembar saham bukan lah alasan utama para investor untuk menanamkan modal pada perusahaan tersebut atau mentransaksikan saham yang telah menjadi emiten dilantai bursa.

9. Dalam penelitian ini didapatkan hasil bahwa pengaruh Harga Saham terhadap Indeks Harga Saham tidak berpengaruh signifikan. Hal ini dikarenakan transaksi faktor fundamental seperti keadaan ekonomi ataupun politik tidak mempengaruhi jumlah transaksi atau volume transaksi Indeks Harga Saham itu sendiri tetapi berpengaruh terhadap harga saham yang fluktuasi naik dan turunnya lebih cepat. 


\section{Rekomendasi}

1. Untuk peneliti selanjutnya, diusahakan perusahaan yang menjadi sampel penelitian bisa dibedakan dari penelitian ini. Mungkin dengan berbedanya sampel penelitian yang diambil, maka variabel Profitabilitas berpengaruh terhadap variabel Harga Saham. Meskipun dalam penelitian ini ternyata rasio profitabilitas tidak berpengaruh terhadap Harga Saham dan tidak perpengaruh terhadap Indeks Harga Saham.

2. Untuk memberikan hasil yang lebih baik, rasio-rasio yang lain dalam rasio profitabilitas dan rasio pasar selain rasio yang sudah ada dalam penelitian ini dimasukkan menjadi prediktor, sehingga analisis tentang harga saham menjadi luas dan dapat memberikan informasi yang lebih baik kepada para pengambil kebijakan investasi di sektor saham pada umumnya.

3. Pengembangan metode penelitian khususnya mengenai periode pengamatan dapat dikembangan dalam periode yang lebih lama.

4. Bagi para investor yang akan menanamkan sejumlah modal untuk mendapatkan keuntungan dimasa depan diharapkan melihat dan mencari informasi terlebih dahulu mengenai informasi perusahaan tersebut.

5. Semoga dalam penelitian ini dapat menjadi pertimbangan bagi para investor yang akan menginvestasikan sejumlah dana pada perusahaan yang go public.

\section{Daftar Pustaka}

Ghozali, Imam. 2002. Aplikasi Analisis Multivariate dengan Program SPSS. Semarang: Badan Penerbit Universitas Diponegoro.

Halim, Abdul, 2003. Analisis Investasi. Salemba Empat, Jakarta.

Husnan S. 2003. Dasar-dasar Manajemen Kauangan. Edisi ke empat. Yogyakarta. UPP AMP YKPN.

2001. Dasar-Dasar Teori Portofolio dan Analisis Sekuritas, Edisi Ketiga, AMP YKPN, Yogyakarta.

Keown, 2004, Manajemen Keuangan Prinsip-prinsip dan Aplikasi, Jakarta, Indeks.
Koetin, E.A. 1997. Pasar Modal Indonesia. Jakarta: Pustaka Sinar Harapan.

Riyanto, Bambang. 1995. Dasar-dasar Pembelanjaan Perusahaan. Yogyakarta: BPFE UGM. 